\title{
ChemComm
}

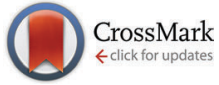

Cite this: Chem. Commun., 2014, 50, 12753

Received 29th July 2014, Accepted 26th August 2014

DOI: $10.1039 / \mathrm{c} 4 \mathrm{cc} 05905 \mathrm{k}$

www.rsc.org/chemcomm

\section{Bypassing a highly unstable frustrated Lewis pair: dihydrogen cleavage by a thermally robust silylium-phosphine adduct $\dagger$}

\author{
Thomas J. Herrington, Bryan J. Ward, Laurence R. Doyle, Joe McDermott, \\ Andrew J. P. White, Patricia A. Hunt* and Andrew E. Ashley*
}

\begin{abstract}
The thermally robust silylium complex $\left[\mathrm{Pr}_{3} \mathrm{Si}-\mathrm{PtBu}_{3}\right]^{+}\left[\mathrm{B}\left(\mathrm{C}_{6} \mathrm{~F}_{5}\right)_{4}\right]^{-}$(1) activates $\mathrm{H}_{2} / \mathrm{D}_{2}$ at $90^{\circ} \mathrm{C}(\mathrm{PhCl})$; no evidence for dissociation into the separated Lewis pair is found. DFT calculations show $\mathrm{H}_{2}$ cleavage proceeds via Si-P bond elongation to form an encounter complex directly from the adduct, thus avoiding the non-isolable $\mathrm{iPr}_{3} \mathrm{Si}^{+}-\mathrm{PtBu}_{3}$ FLP.
\end{abstract}

Since their discovery in 2006, 'frustrated Lewis pairs' (FLPs) have continued to provide a fresh and novel approach to the field of bond activation chemistry. ${ }^{1}$ FLPs can be defined as combinations of a Lewis acid and base which, by dint of steric hindrance, are unable to datively bind in the classical manner, leading to unquenched reactivity capable of activating small molecules. One of the most exciting properties of FLPs is their ability to induce heterolytic cleavage of $\mathrm{H}_{2}$ into protic and hydridic components $\left(\mathrm{H}^{+} / \mathrm{H}^{-}\right),{ }^{2}$ which can subsequently be transferred to reducible substrates either stoichiometrically (e.g. carbonyls, $\left.\mathrm{CO}_{2}\right)^{3}$ or catalytically (e.g. imines, silyl enol ethers, alkenes). ${ }^{4}$ By far the most commonly used Lewis acids are organometallics of the Group 13 elements $\left(e . g . \mathrm{R}_{3} \mathrm{E}\right.$; $\mathrm{E}=\mathrm{B}$ or $\mathrm{Al}, \mathrm{R}=$ electron-deficient organyl), among which $\mathrm{B}\left(\mathrm{C}_{6} \mathrm{~F}_{5}\right)_{3}$ remains prevalent. Silylium ions $\left(\mathrm{R}_{3} \mathrm{Si}^{+}\right)$are both isoelectronic and isolobal with this class of compounds and, because of their potent electrophilicity, ${ }^{5}$ can demonstrate similar FLP reactivity when employed as the Lewis acid partner. However, there are few reports of stable $\mathrm{R}_{3} \mathrm{Si}^{+}$cations, which is attributed to the difficulties in stabilising the diffuse $3 p$ Si valence orbital either through hyper- or $\pi$-conjugation. ${ }^{6}$ This property explains, in part, their voracious affinity for nucleophiles; even traditionally 'inert' arene solvents ${ }^{7}$ and weakly coordinating anions (WCAs) ${ }^{8}$ can demonstrate interactions with the silicon centre. The work of Ozerov et al. reflects this extreme appetite for $\sigma$ and $\pi$ donors,

Department of Chemistry, Imperial College London, Exhibition Road,

London SW7 2AZ, U.K. E-mail: a.ashley@imperial.ac.uk;

Web: http://www3.imperial.ac.uk/people/a.ashley

$\dagger$ Electronic supplementary information (ESI) available: Experimental section including computational details, characterisation data and copies of the NMR spectra compounds and reactions. CCDC 970728. For ESI and crystallographic data in CIF or other electronic format see DOI: 10.1039/c4cc05905k in which decomposition of the robust $\left[\mathrm{B}_{(}\left(\mathrm{C}_{6} \mathrm{~F}_{5}\right)_{4}\right]^{-}$WCA was observed when heated in the presence of $\mathrm{Et}_{3} \mathrm{Si}^{+},{ }^{9}$ presumably via $\left[\mathrm{C}_{6} \mathrm{~F}_{5}\right]^{-}$ abstraction or C-F activation. ${ }^{10}$ Such indiscriminate reactivity may be suppressed via incorporation of intramolecular donors which moderate the potent electrophilicity while preserving sufficient reactivity for catalysis. In this respect, Oestreich and co-workers used the ferrocene-stabilised silylium ion $\left[\left(\mathrm{C}_{5} \mathrm{H}_{5}\right) \mathrm{Fe}\left(\mathrm{C}_{5} \mathrm{H}_{4} \mathrm{SitBuMe}\right)\right]^{+}$to selectively and catalytically hydrosilylate various ketones to the corresponding alkyl/silyl ethers $\left(\mathrm{RR}^{\prime} \mathrm{CH}-\mathrm{O}-\mathrm{SiR}_{3} ; \mathrm{R} / \mathrm{R}^{\prime}=\right.$ alkyl $) ;{ }^{11}$ by contrast the fully reduced alkanes $\mathrm{R}-\mathrm{CH}_{2}-\mathrm{R}^{\prime 12}$ can be isolated when the 'untamed' ' $\left[\mathrm{R}_{3} \mathrm{Si}\right]^{+}$', is used as catalyst. Steric protection of the $\mathrm{Si}$ centre has also been adopted to prevent undesired silylation of aromatic solvents, as documented by Müller et al. Here, bulky triarylsilylium compounds $\left(\mathrm{Ar}_{3} \mathrm{Si}^{+} ; \mathrm{Ar}=\mathrm{C}_{6} \mathrm{H}_{6-x} \mathrm{Me}_{x}, x=3-5\right)$, in conjunction with phosphine $\left(\mathrm{R}_{3} \mathrm{P} ; \mathrm{R}=\right.$ alkyl, aryl $)$ or silylene bases, ${ }^{13}$ are shown to generate FLPs that engage in $\mathrm{H}_{2}$ cleavage. Nonetheless, eventual solution-phase decomposition of these FLPs under ambient conditions was attributed to the long-term instability of the $\mathrm{Ar}_{3} \mathrm{Si}^{+}$ ions, which leads to protonated arene products. ${ }^{14}$

Herein we report the synthesis and characterisation of a classical donor-acceptor complex between $t \mathrm{Bu}_{3} \mathrm{P}$ and the less sterically encumbered, highly reactive, silylium ion $\mathrm{iPr}_{3} \mathrm{Si}^{+}$. We show that the use of a Lewis adduct considerably stabilises the $\mathrm{R}_{3} \mathrm{Si}^{+}$moiety, in comparison with the previously studied $\mathrm{Ar}_{3} \mathrm{Si}^{+}$ species. Furthermore, this species is shown to heterolytically cleave $\mathrm{H}_{2}$, the mechanism of which avoids the formation of a presumably highly unstable $\mathrm{iPr}_{3} \mathrm{Si}^{+}-\mathrm{P} t \mathrm{Bu}_{3}$ separated Lewis pair.

Treatment of $\mathrm{iPr}_{3} \mathrm{SiH}$ with $\left[\mathrm{Ph}_{3} \mathrm{C}\right]\left[\mathrm{B}\left(\mathrm{C}_{6} \mathrm{~F}_{5}\right)_{4}\right]$ (Bartlett-CondonSchneider hydride transfer ${ }^{15}$ in chlorobenzene afforded solutions of $\left[\mathrm{iPr}_{3} \mathrm{Si} \cdot \mathrm{ClPh}\right]^{+}$, as previously described. ${ }^{16}$ Subsequent in situ reaction with $t \mathrm{Bu}_{3} \mathrm{P}$ furnished $\left.\left[\mathrm{iPr}_{3} \mathrm{Si}-\mathrm{P}_{\mathrm{Bu}}\right]_{3}\right]^{+}\left[\mathrm{B}\left(\mathrm{C}_{6} \mathrm{~F}_{5}\right)_{4}\right]^{-}$(1), upon precipitation with hexanes and recrystallisation from $\mathrm{PhCl}$, in excellent yield (Scheme 1). 1 has been characterised by ${ }^{1} \mathrm{H},{ }^{13} \mathrm{C}$, ${ }^{29} \mathrm{Si}$ and ${ }^{31} \mathrm{P}$ NMR spectroscopy, high resolution MS (ES+), and elemental analysis (see ESI†).

Slow cooling of a PhF solution of $\mathbf{1}$ to $-25{ }^{\circ} \mathrm{C}$ produced large colourless plates which were suitable for single crystal X-ray diffraction, $¥$ and the solid state structure is shown in Fig. 1 . 


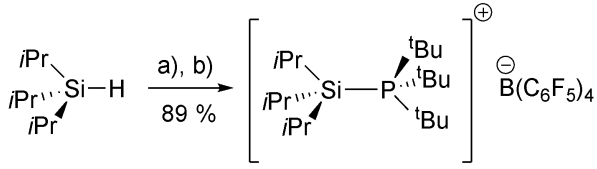

$$
\begin{aligned}
& 1
\end{aligned}
$$

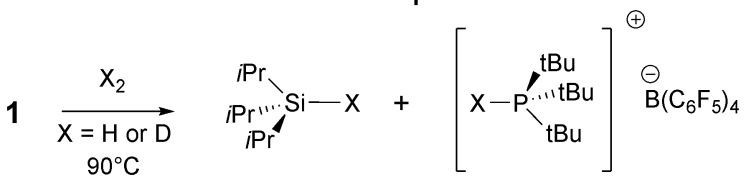

Scheme 1 Synthesis of 1 and subsequent reactivity with $\mathrm{H}_{2} / \mathrm{D}_{2}\left(\mathrm{C}_{6} \mathrm{D}_{5} \mathrm{Cl}\right.$ or $\mathrm{C}_{6} \mathrm{H}_{5} \mathrm{Cl}$ solution, $0.096 \mathrm{M} ; \mathrm{H}_{2}$ and $\mathrm{D}_{2}$ experiments respectively, 4 bar). Reagents and conditions: (a) (i) $\left[\mathrm{Ph}_{3} \mathrm{C}\right]\left[\mathrm{B}\left(\mathrm{C}_{6} \mathrm{~F}_{5}\right)_{4}\right], \mathrm{PhCl}, \mathrm{RT},-\mathrm{Ph}_{3} \mathrm{CH}$; (b) $t_{\mathrm{Bu}} \mathrm{P}$ added in situ.
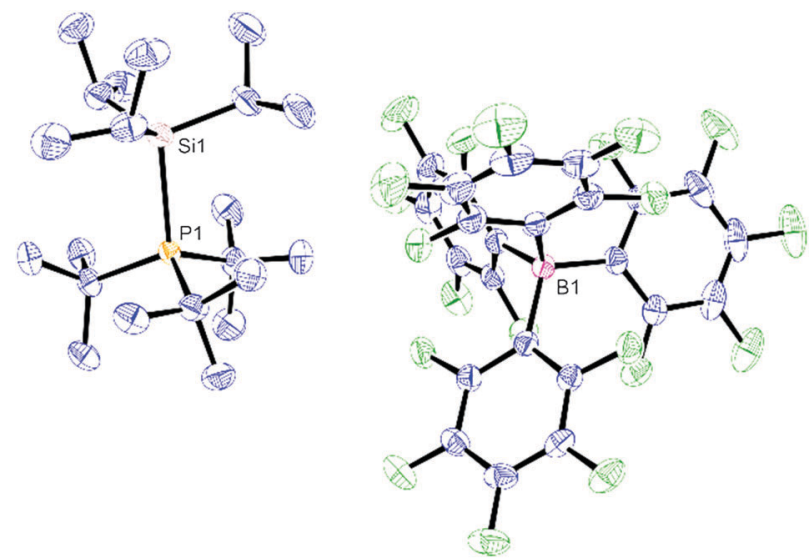

Fig. 1 ORTEP plot of the X-ray structure of 1 . C atoms blue, $\mathrm{P}$ atom orange, $\mathrm{B}$ atom pink, $\mathrm{F}$ atoms green and $\mathrm{Si}$ atom light brown. $\mathrm{H}$ atoms have been removed for clarity, and thermal ellipsoids are shown at $50 \%$ probability; Si1-P1 = 2.4843(5) $\AA$

The $\left[\mathrm{iPr}_{3} \mathrm{Si}-\mathrm{P} t \mathrm{Bu}_{3}\right]^{+}$fragment in $\mathbf{1}$ is derived from a donoracceptor interaction between the $\mathrm{iPr}_{3} \mathrm{Si}^{+}$moiety and $t \mathrm{Bu}_{3} \mathrm{P}$, as exemplified by the pyrimidalisation about the $\mathrm{Si}$ atom (0.5765(11) A deviation from the plane of the three $\mathrm{C}$ atoms in the $\mathrm{C}_{3} \mathrm{Si}$ unit). The $\mathrm{C}-\mathrm{Si}-\mathrm{C}$ bond angles, which range between 110.51(8) and 111.86(9) ${ }^{\circ}$, are much closer to the idealised tetrahedral angle $\left(109.5^{\circ}\right)$ than those found in ${ }^{i P r}{ }_{3} \mathrm{Si}\left(\mathrm{CHB}_{11} \mathrm{H}_{5} \mathrm{Cl}_{6}\right)$ $\left(117.3^{\circ}\right),{ }^{8}$ which possesses significant silylium character and hence approaches a trigonal geometry. The $\left[\mathrm{B}\left(\mathrm{C}_{6} \mathrm{~F}_{5}\right)_{4}\right]^{-}$anions are well separated from the cations, with no close $\mathrm{Si}$ to $\mathrm{F}$ contacts, and hence are non-coordinating. However, the $\mathrm{Si}-\mathrm{P}$ bond distance is rather long (2.4843(5) $\AA$; within the top $2 \%$ of those reported in the CSD), and may be compared to $\left[\mathrm{PhMe}_{2} \mathrm{Si}-\mathrm{P} t \mathrm{Bu}_{3}\right]^{+}\left[\mathrm{HB}\left(\mathrm{C}_{6} \mathrm{~F}_{5}\right)_{3}\right]^{-}$ $(\mathrm{Si}-\mathrm{P}=2.376(2) \AA)$, which has been prepared from reaction of $\mathrm{PhMe}_{2} \mathrm{SiH}$ and the FLP system $t \mathrm{Bu}_{3} \mathrm{P} / \mathrm{B}\left(\mathrm{C}_{6} \mathrm{~F}_{5}\right)_{3}{ }^{17}$ This increased distance may be attributed to the higher degree of steric strain due to crowding between the organic groups along the Si-P axis.

$\mathrm{PhCl}$ solutions of $\mathbf{1}$ proved to be stable for at least several months at room temperature, and these can be heated at $90{ }^{\circ} \mathrm{C}$ for $24 \mathrm{~h}$ without evidence of decomposition. ${ }^{1} \mathrm{H}$ and ${ }^{13} \mathrm{C}$ NMR spectra $\left(\mathrm{C}_{6} \mathrm{D}_{5} \mathrm{Cl} ; 298 \mathrm{~K}\right)$ of $\mathbf{1}$ are commensurate with the solid state structure, and the upfield ${ }^{29} \mathrm{Si}$ resonance $(\delta=43.1 \mathrm{ppm}$, ${ }^{1} J_{\mathrm{SiP}}=23 \mathrm{~Hz}$ ) reveals the $\mathrm{Si}-\mathrm{P}$ bond to be intact in solution.
However, the coupling constant is noticeably smaller than those reported for $\left[\left(\mathrm{C}_{6} \mathrm{Me}_{5}\right)_{3} \mathrm{Si}-\mathrm{PEt}_{3}\right]^{+}\left[\mathrm{B}\left(\mathrm{C}_{6} \mathrm{~F}_{5}\right)_{4}\right]^{-}$or zwitterionic $\left[\mathrm{Mes}_{2}\left(\mathrm{SiPh}_{2} \mathrm{H}\right) \mathrm{P}^{+} \mathrm{CH}_{2} \mathrm{CH}_{2} \mathrm{~B}^{-} \mathrm{H}\left(\mathrm{C}_{6} \mathrm{~F}_{5}\right)_{2}\right]\left({ }^{1} J_{\mathrm{SiP}}=41.2\right.$ and $48.5 \mathrm{~Hz}$, respectively), ${ }^{14,18}$ and the ${ }^{31} \mathrm{P}$ NMR resonance $(\delta=57.3 \mathrm{ppm}$, $298 \mathrm{~K})$ is close to that observed for free $t \mathrm{Bu}_{3} \mathrm{P}(\delta=62.0 \mathrm{ppm}$, $298 \mathrm{~K})$; collectively these data would suggest a weak $\mathrm{Si}-\mathrm{P}$ bond.

In contrast to the results obtained using the silylium FLPs, $\left(\mathrm{C}_{6} \mathrm{Me}_{5}\right)_{3} \mathrm{Si}^{+} / \mathrm{PR}_{3}{ }^{14}$ admission of $\mathrm{H}_{2}$ to $\mathbf{1}$ (4 bar, $\mathrm{C}_{6} \mathrm{D}_{5} \mathrm{Cl}$ solvent) at room temperature led to no discernible reaction. However, heating these solutions to $90{ }^{\circ} \mathrm{C}$ led to complete consumption of the adduct (8 hours; Scheme 1), concomitant with formation of $\mathrm{iPr}_{3} \mathrm{Si}-\mathrm{H}\left({ }^{1} \mathrm{H} \mathrm{NMR}, \delta=3.43 \mathrm{ppm}\right)$ and phosphonium borate $\left[t \mathrm{Bu}_{3} \mathrm{P}-H\right]^{+}\left[\mathrm{B}\left(\mathrm{C}_{6} \mathrm{~F}_{5}\right)_{4}\right]^{-}\left({ }^{1} \mathrm{H} \mathrm{NMR}, \delta=4.17 \mathrm{ppm},{ }^{1} J_{\mathrm{HP}}=430 \mathrm{~Hz} ;{ }^{31} \mathrm{P}\right.$ $\left\{{ }^{1} \mathrm{H}\right\} \mathrm{NMR}, \delta=60.3 \mathrm{ppm}$ ) in high conversion (90-94\%, four runs). ${ }^{19}$ Conducting these experiments under $\mathrm{D}_{2}\left(\mathrm{C}_{6} \mathrm{H}_{5} \mathrm{Cl}\right.$ solvent) gave the deuterated products $\mathrm{iPr}_{3} \mathrm{Si}-\mathrm{D}$ and $\left[t \mathrm{Bu}_{3} \mathrm{P}-\mathrm{D}\right]^{+}$, as shown by ${ }^{2} \mathrm{H},{ }^{31} \mathrm{P}$ and ${ }^{29} \mathrm{Si}$ NMR spectroscopy (see ESI $\dagger$ for details); ${ }^{20}$ this conclusively shows that $\mathrm{H}_{2} / \mathrm{D}_{2}$ is the source of $\mathrm{H} / \mathrm{D}$ atoms in the formally hydridic silane, and protic phosphonium ion. ${ }^{21}$ Upon reaction completion, ${ }^{19} \mathrm{~F}$ and ${ }^{11} \mathrm{~B}$ NMR spectra showed only resonances corresponding to the $\left[\mathrm{B}\left(\mathrm{C}_{6} \mathrm{~F}_{5}\right)_{4}\right]^{-}$counterion, demonstrating that silylium-mediated decomposition of the anion had not occurred. Since neither $\left[\mathrm{H}-\mathrm{B}\left(\mathrm{C}_{6} \mathrm{~F}_{5}\right)_{3}\right]^{-}$nor $\mathrm{B}\left(\mathrm{C}_{6} \mathrm{~F}_{5}\right)_{3}$ could be observed in solution, the possibility that $\mathrm{H}_{2}$ cleavage involves the known $t \mathrm{Bu}_{3} \mathrm{P} /$ $\mathrm{B}\left(\mathrm{C}_{6} \mathrm{~F}_{5}\right)_{3}$ FLP pathway ${ }^{17}$ may be discounted.

In order to investigate the possibility that $\mathbf{1}$ may dissociate in $\mathrm{PhCl}$ solution to generate $t \mathrm{Bu}_{3} \mathrm{P}$ and solvated silylium ion, $\left[\mathrm{iPr}_{3} \mathrm{Si}\right.$. $\mathrm{ClPh}]^{+}$, a variable temperature (VT) ${ }^{31} \mathrm{P}$ NMR experiment was conducted $\left(\mathrm{Ph}_{3} \mathrm{P}\right.$ internal capillary reference; see Fig. S7 in ESI $\left.\dagger\right)$. At low temperature the spectrum shows a very broad resonance $\left(\delta=54.5 \mathrm{ppm},-40{ }^{\circ} \mathrm{C}\right)$ which moves progressively downfield $\left(\delta=60.6 \mathrm{ppm}, 100{ }^{\circ} \mathrm{C}\right)$, and markedly sharpens. However, it should be noted that the ${ }^{31} \mathrm{P}$ NMR resonance for $t \mathrm{Bu}_{3} \mathrm{P}$ also moves by $c a$. $\Delta \delta=6$ ppm over the same temperature range and the behaviour is likely due to a temperature-induced shift for both species. Furthermore, addition of $t \mathrm{Bu}_{3} \mathrm{P}$ (1-10 eq., $\mathrm{PhCl}, 100{ }^{\circ} \mathrm{C}$ ) to 1 produced ${ }^{31} \mathrm{P}$ NMR spectra consisting only of their separate respective resonances; neither a discernible change in the lineshape nor chemical shift position of the adduct was observed. If rapid exchange between 1 and appreciable concentrations of dissociated products were indeed occurring, introduction of extraneous $t \mathrm{Bu}_{3} \mathrm{P}$ would be expected to lead to a significant perturbation of the ${ }^{31} \mathrm{P}$ NMR resonance of 1 . Finally, we synthesised $\left[\mathrm{iPr}_{3} \mathrm{Si} \cdot \mathrm{ClPh}\right]^{+}\left[\mathrm{B}\left(\mathrm{C}_{6} \mathrm{~F}_{5}\right)_{4}\right]^{-}$in order to investigate its reactivity under the conditions of $\mathrm{H}_{2}$ activation, in the absence of added phosphine: at $90{ }^{\circ} \mathrm{C}$ this species degraded (40 $\mathrm{min}$ ) via decomposition of the anion, producing $\mathrm{B}\left(\mathrm{C}_{6} \mathrm{~F}_{5}\right)_{3}, \mathrm{iPr}_{3} \mathrm{SiF}\left({ }^{19} \mathrm{~F} \mathrm{NMR} \delta=-185.0 \mathrm{ppm} ;{ }^{1} J_{\mathrm{FSi}}=298 \mathrm{~Hz}\right)$ and other unidentified products. This implies that, if dissociation of $t \mathrm{Bu}_{3} \mathrm{P}$ from 1 were to occur and generate $\mathrm{iPr}_{3} \mathrm{Si}^{+}$or (more likely) $\left[\mathrm{iPr}_{3} \mathrm{Si} \cdot \mathrm{ClPh}\right]^{+}$, the rate at which this cation reacts with $\left[\mathrm{B}\left(\mathrm{C}_{6} \mathrm{~F}_{5}\right)_{4}\right]^{-}$ would greatly exceed the observed rate of $\mathrm{H}_{2}$ activation.

In order to determine whether thermally-induced dissociation of 1 (and hence a typical FLP-mediated mechanism) was responsible for $\mathrm{H}_{2}$ heterolysis, we examined this system further using DFT calculations. The results of our computational calculations (M06-2X/6-311+G(d,p) level of theory; see ESI $\dagger$ ) 


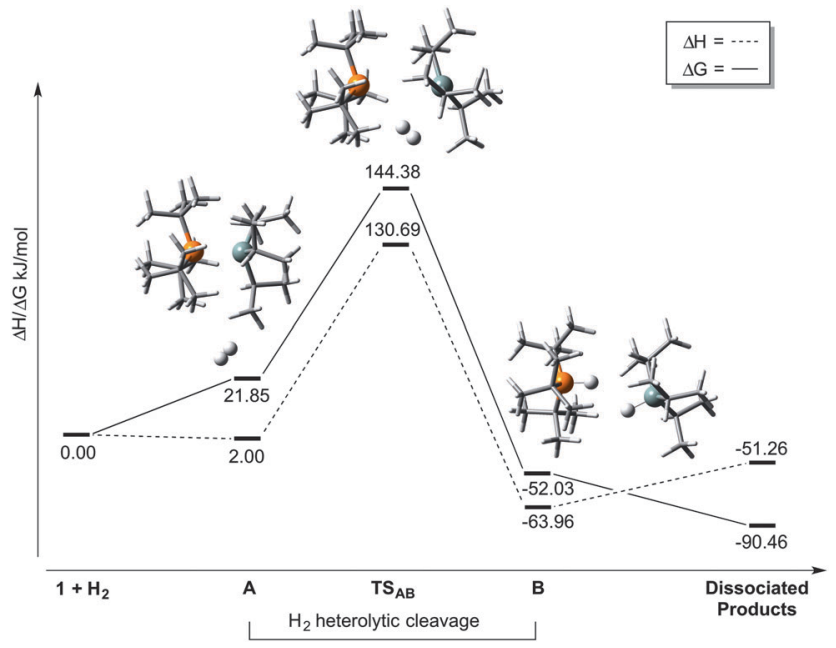

Scheme 2 Solvent-phase enthalpy $(\Delta H)$ and Gibbs free energy $(\Delta G)$ profile for $\mathrm{H}_{2}$ activation mediated by 1 in $\mathrm{PhCl}$ solution, showing intermediates and transition states along the reaction coordinate $(T=363 \mathrm{~K})$. $\mathrm{P}$ atom orange and $\mathrm{Si}$ atom pale green.

which took into account secondary (conductor-like polarizable continuum model; C-PCM) solvent interaction, are presented in Scheme 2 (and Table S1, ESI $\dagger$ ). Various conformations of 1 were identified (Table S2, ESI $\dagger$ ), which are separated in free energy by only $c a$. $13-30 \mathrm{~kJ} \mathrm{~mol}^{-1}$; this lends support to the solutionphase VT ${ }^{31} \mathrm{P}$ NMR data whereby the dynamic lineshape observed for $\mathbf{1}$ at low temperatures can be explained through interconversion between conformers. In total, two intermediates ( $\mathbf{A}$ and $\mathbf{B}$ ), and a single transition state for their interconversion $\left(\mathbf{T S}_{\mathbf{A B}}\right)$ were located along the reaction coordinate for $\mathrm{H}_{2}$ activation, starting from the lowest energy conformer of $\mathbf{1}$.

On progressing to the transition state for $\mathrm{H}_{2}$ activation, $\mathbf{T S}_{\mathbf{A B}}$, the Si $\cdots \mathrm{P}$ distance lengthens considerably (Table 1), to an extent that is greater than the sum of the van der Waals radii of the elements (3.90 ̊̊). ${ }^{22}$ The incipient cavity accompanying this bond elongation permits entry of a molecule of $\mathrm{H}_{2}$ while attractive electrostatic $\mathrm{P} \cdots \mathrm{Si}$ and secondary van der Waals interactions between $\mathrm{iPr}_{3} \mathrm{Si}$ and $t \mathrm{Bu}_{3} \mathrm{P}$ fragments lead to binding beyond covalent distances, thus retarding $t \mathrm{Bu}_{3} \mathrm{P}$ dissociation. This factor explains the experimental observation that the rate of $\mathrm{H}_{2}$ activation outcompetes decomposition, (which would be anticipated to be the faster process if dissociation to a true FLP were to occur at these elevated temperatures). A range of van der Waals interactions give rise to QTAIM bond critical points (BCP) between $\mathrm{C}-\mathrm{H} \cdots \mathrm{H}-\mathrm{C}$ and $\mathrm{C}-\mathrm{H} \cdots \mathrm{P}$ (Tables S3 and S4, ESI $\dagger$ )

Table 1 Pertinent interatomic distances corresponding to selected $\mathrm{H}_{2}$ activation intermediates and transition states $(\AA)$

\begin{tabular}{lllll}
\hline & $\mathrm{Si} \cdots \mathrm{P}$ & $\mathrm{H} \cdots \mathrm{H}$ & $\mathrm{Si} \cdots \mathrm{H}$ & $\mathrm{P} \cdots \mathrm{H}$ \\
\hline $\mathbf{1}$ & 2.50 & $0.74^{a}$ & & \\
$\mathbf{A}$ & 2.50 & 0.74 & 5.36 & 6.09 \\
TS $_{\text {AB }}$ & 4.10 & 0.74 & 2.87 & 2.98 \\
$\mathbf{B}$ & 4.63 & 2.34 & 1.50 & 1.41 \\
Products & - & - & 1.50 & 1.40
\end{tabular}

${ }^{a}$ Bond length corresponding to free $\mathrm{H}_{2}$. which appear to hold the fragments in place, fulfilling a similar role to those of the $\mathrm{C}-\mathrm{H} \cdots \mathrm{F}$ H-bonds reported for the frustrated encounter complex $\left[t \mathrm{Bu}_{3} \mathrm{P}\right] \cdots\left[\mathrm{B}\left(\mathrm{C}_{6} \mathrm{~F}_{5}\right)_{3}\right]$ (the precursor species to $\mathrm{H}_{2}$ cleavage by that FLP system). ${ }^{23}$ It is notable that the B $\cdots P$ distance in the latter $(4.20 \AA)$ compares well with the $\mathrm{Si} \cdots \mathrm{P}$ length in $\mathbf{T S}_{\mathbf{A B}}$, yet both are appreciably shorter than that those calculated for the 'encounter complexes' in Müller's $\left(\mathrm{C}_{6} \mathrm{Me}_{5}\right)_{3} \mathrm{Si}^{+} /$ $\mathrm{PR}_{3}$ systems ( $\mathrm{R}=$ alkyl, aryl; range 4.45-5.73 $\left.\mathrm{A}\right)$; this likely reflects the much greater steric bulk of the $\mathrm{Ar}_{3} \mathrm{Si}^{+}$fragment in these 'true' FLPs. ${ }^{14}$ Heterolytic cleavage of $\mathrm{H}_{2}$ subsequently proceeds to give $\left[t \mathrm{Bu}_{3} \mathrm{P}-\mathrm{H}\right]^{+}$and $\mathrm{H}-\mathrm{SiiPr}_{3}$ as a dihydrogen bonded intermediate (B), after which dissociation to form the free products is strongly entropically driven. The TS molecular orbitals exhibit $\mathrm{H}_{2}$ contributions (Fig. S19, ESI $\dagger$ ) while BCPs from $\mathrm{H}_{2}$ to both $\mathrm{P}$ and $\mathrm{Si}$ are obtained (Table S5, ESI $\dagger$ ). Moreover, the early TS exhibits nascent NBO P $\rightarrow \mathrm{H}_{2}\left(\sigma^{*}\right)$ and $\mathrm{H}_{2}(\sigma) \rightarrow$ Si electron transfer, approximately equal to 8 and $34 \mathrm{~kJ} \mathrm{~mol}^{-1}$ respectively, which are expected to increase as the reaction proceeds. Heterolysis of $\mathrm{H}_{2}$ in this manner is consistent with the electron transfer model, ${ }^{24}$ with no observable deviation in $\mathrm{H}-\mathrm{H}$ distance between that in $\mathbf{T S}_{\mathbf{A B}}$ and free $\mathrm{H}_{2}$, denoting an early transition state.

Formation of $\mathbf{T S}_{\mathbf{A B}}$ is both enthalpically unfavourable owing to the weakening of the Si-P interaction, and entropically unfavourable due to the increased ordering as a result of $\mathrm{H}_{2}$ coordination (Table S1, ESI $\uparrow$ ). The substantial energy barrier (122.53 $\mathrm{kJ} \mathrm{mol}^{-1} ; \mathbf{A} \rightarrow \mathbf{T S}_{\mathbf{A B}}$ ) associated with $\mathrm{H}_{2}$ activation is testament to the strong $\mathrm{Si}-\mathrm{P}$ dative bond in $\mathbf{1}$ and explains the elevated temperatures required experimentally to achieve bond elongation and access the encounter complex. Comparable rate-determining steps have been observed elsewhere in the literature; Lammertsma et al. report that the experimentally observed insertion of $\mathrm{CO}_{2}$ into dimeric $\mathrm{P} / \mathrm{Al}$-based Lewis pairs proceeds at room temperature, despite having computed a significant energy barrier $\left(c a .140 \mathrm{~kJ} \mathrm{~mol}^{-1}\right) .^{25}$

Whilst a number of Lewis pairs have been documented that exhibit classical/frustrated borderline reactivity with $\mathrm{H}_{2}$ or alkynes ${ }^{26}$ spectroscopic evidence for the existence of the dissociated constituents has always been demonstrated, due to the stability of the Lewis acid as an independent entity. In our particular example, however, we have shown that the critical development of an encounter complex prior to $\mathrm{H}_{2}$ activation can be achieved directly from the Lewis pair adduct via simple bond elongation and weakening, obviating the need for the formation of a true FLP; this is especially important when the Lewis acid partner (in our case $\operatorname{iPr}_{3} \mathrm{Si}^{+}$) is too reactive to isolate in the free form.

In conclusion, we have shown that a classical donor-acceptor adduct incorporating a highly electrophilic trialkylsilylium ion can activate $\mathrm{H}_{2}$; this reaction is thus not rigidly confined to truly separated $\mathrm{R}_{3} \mathrm{Si}^{+}$/base FLP combinations. Indeed, the formation of a stable adduct incorporating such species may provide a general strategy towards the protection of highly reactive Lewis acids/bases in Lewis pair systems, without excluding such systems from participating in characteristic FLP-type chemistry. We are currently exploring the small molecule reactivity of other $\left[\mathrm{R}_{3} \mathrm{Si}-(\text { base })\right]^{+}$adducts, in addition to investigating their 
potential use in the catalytic hydrogenation of unsaturated substrates.

The authors wish to acknowledge the Royal Society for a University Research Fellowship (AEA), the EPSRC for studentship funding (TJH and BJW), and Dr Richard Matthews for his assistance with the QTAIM analysis.

\section{Notes and references}

\$ Crystallographic data for $1: \mathrm{C}_{45} \mathrm{H}_{48} \mathrm{BF}_{20} \mathrm{PSi}, M=1038.70$, triclinic, $a=$ 11.6772(5) $\AA$, $b=12.5736(4) \AA, c=17.0286(6) \AA, \alpha=79.442(3)^{\circ}, \beta=$ $75.102(3)^{\circ}, \gamma=77.292(3)^{\circ}, U=2335.61(15) \AA^{3}, T=173 \mathrm{~K}$, space group $P \overline{1}$ (no. 2), $Z=2, \rho_{\text {calcd }}=1.477 \mathrm{~g} \mathrm{~cm}^{-3}, \mu\left(\mathrm{Cu}_{\mathrm{K} \alpha}\right)=1.792 \mathrm{~mm}^{-1}$, colourless blocks, Agilent Xcalibur PX Ultra A diffractometer; 8923 independent measured reflections $\left(R_{\text {int }}=0.0180\right), F^{2}$ refinement, ${ }^{27} R_{1}(\mathrm{obs})=0.0354$, $\mathrm{w} R_{2}(\mathrm{all})=0.0948,7708$ independent observed absorption-corrected reflections $\left[\left|F_{\mathrm{o}}\right|>4 \sigma\left(\left|F_{\mathrm{o}}\right|\right), 2 \theta_{\max }=147^{\circ}\right], 613$ parameters. CCDC 970728.

1 (a) G. Erker and D. W. Stephan, Frustrated Lewis Pairs I: Uncovering and Understanding, Top. Curr. Chem., Springer GmbH, Berlin, 2013, pp. 1-350; (b) G. Erker and D. W. Stephan, Frustrated Lewis Pairs II: Expanding The Scope, Top. Curr. Chem., Springer GmbH, Berlin, 2013, pp. 1-350.

2 (a) D. W. Stephan and G. Erker, Angew. Chem., Int. Ed., 2010, 49, 46; (b) G. C. Welch, R. R. S. Juan, J. D. Masuda and D. W. Stephan, Science, 2006, 314, 1124.

3 (a) A. E. Ashley, A. L. Thompson and D. O'Hare, Angew. Chem., Int. Ed., 2009, 48, 9839; (b) G. Menard and D. W. Stephan, J. Am. Chem. Soc., 2010, 132, 1796; (c) V. Sumerin, F. Schulz, M. Nieger, M. Leskela, T. Repo and B. Rieger, Angew. Chem., Int. Ed., 2008, 47, 6001.

4 (a) D. W. Stephan, S. Greenberg, T. W. Graham, P. Chase, J. J. Hastie, S. J. Geier, J. M. Farrell, C. C. Brown, Z. M. Heiden, G. C. Welch and M. Ullrich, Inorg. Chem., 2011, 50, 12338; (b) L. Greb, S. Tussing, B. Schirmer, P. Ona-Burgos, K. Kaupmees, M. Lokov, I. Leito, S. Grimme and J. Paradies, Chem. Sci., 2013, 4, 2788.

5 C. A. Reed, Acc. Chem. Res., 1998, 31, 325.

6 A. Schulz and A. Villinger, Angew. Chem., Int. Ed., 2012, 51, 4526.

7 J. B. Lambert, S. H. Zhang, C. L. Stern and J. C. Huffman, Science, 1993, 260, 1917.

8 Z. W. Xie, J. Manning, R. W. Reed, R. Mathur, P. D. W. Boyd, A. Benesi and C. A. Reed, J. Am. Chem. Soc., 1996, 118, 2922.

9 C. Douvris and O. V. Ozerov, Science, 2008, 321, 1188.

10 M. F. Ibad, P. Langer, A. Schulz and A. Villinger, J. Am. Chem. Soc., 2011, 133, 21016.

11 K. Muether and M. Oestreich, Chem. Commun., 2011, 47, 334.

12 M. Kira, T. Hino and H. Sakurai, Chem. Lett., 1992, 555.

13 (a) A. Schaefer, M. Reissmann, A. Schaefer, W. Saak, D. Haase and T. Mueller, Angew. Chem., Int. Ed., 2011, 50, 12636; (b) A. Schäfer, M. Reißmann, A. Schäfer, M. Schmidtmann and T. Müller, Chem. Eur. J., 2014, 20, 9381.

14 M. Reißmann, A. Schäfer, S. Jung and T. Müller, Organometallics, 2013, 32, 6736.

15 P. D. Bartlett, F. E. Condon and A. Schneider, J. Am. Chem. Soc., 1944, 66, 1531.
16 A. Schaefer, W. Saak, D. Haase and T. Mueller, Angew. Chem., Int. Ed., 2012, 51, 2981.

17 G. C. Welch and D. W. Stephan, J. Am. Chem. Soc., 2007, 129, 1880.

18 W. Nie, H. F. T. Klare, M. Oestreich, R. Froehlich, G. Kehr and G. Erker, Z. Naturforsch., B: Chem. Sci., 2012, 67, 987.

191 proved to be highly reactive to even trace amounts of $\mathrm{H}_{2} \mathrm{O}$. Accordingly, the synthesis and solution-phase studies required meticulous drying of solvents, conducting reactions in Teflon ${ }^{\circledR}$ vials, and performing NMR experiments in Teflon ${ }^{\mathbb{R}}$ inserts. Reactions in dilute solution, such as those under $\mathrm{H}_{2}$, invariably become

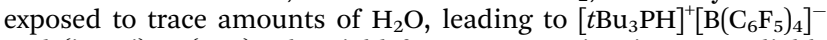
and $\left(\mathrm{iPr}_{3} \mathrm{Si}\right)_{2} \mathrm{O}(2: 1)$. The yield for $\mathrm{H}_{2}$ conversion is most reliably calculated via relative integration of ${ }^{1} \mathrm{H}$ NMR signals for the $\mathrm{iPr}_{3} \mathrm{Si}-\mathrm{H}$ resonance against that of $t \mathrm{Bu}_{3} \mathrm{P}-\mathrm{H}\left(1: 1\right.$ from $\left.\mathrm{H}_{2}\right)$. Accordingly, hydrolysis produces twice the amount of phosphonium salt than the reaction with $\mathrm{H}_{2}$, and accounts for the slightly sub-quantitative yields (90-94\%). In support of this conclusion, ${ }^{2} \mathrm{H}$ NMR spectroscopy of the $\mathrm{D}_{2}$ cleavage reaction shows a 1:1 $t \mathrm{Bu}_{3} \mathrm{P}-\mathrm{D}: \mathrm{D}-\mathrm{Si}_{\mathrm{P}} \mathrm{Pr}_{3}$ ratio, since adventitious moisture is introduced as $\mathrm{H}_{2} \mathrm{O}$, and not $\mathrm{D}_{2} \mathrm{O}$ (see Fig. S8 in ESI $\dagger$ ).

20 A full kinetic study by ${ }^{1} \mathrm{H}$ NMR was hampered by $\mathrm{iPr}_{3} \mathrm{SiH}$ interaction with 1, which masks the actual amount of silane produced until reaction completion (i.e. complete conversion of $\mathbf{1}$ ). This phenomenon has been noted for $\mathrm{R}_{3} \mathrm{Si}(\mu-\mathrm{H}) \mathrm{SiR}_{3}{ }^{+}$species, ${ }^{28}$ wherein the silane proton is rendered invisible to ${ }^{1} \mathrm{H}$ NMR spectroscopy. It is plausible that a similar bridging silane interaction is also operational here.

21 Heating solutions of independently prepared $\left[t \mathrm{Bu}_{3} \mathrm{P}-\mathrm{H}\right]^{+}\left[\mathrm{B}\left(\mathrm{C}_{6} \mathrm{~F}_{5}\right)_{4}\right]^{-}$ with $\mathrm{iPr}_{3} \mathrm{SiH}\left(\mathrm{PhCl}, 90{ }^{\circ} \mathrm{C}, 60 \mathrm{~h}\right)$ led to no reaction, demonstrating that the $\mathrm{H}_{2}$ cleavage reaction is irreversible. Furthermore, conducting the same experiments under $\mathrm{D}_{2}$ did not produce any $\mathrm{HD}$, which would be expected to form due to H/D scrambling.

22 A. Bondi, J. Phys. Chem., 1964, 68, 441.

23 T. A. Rokob, A. Hamza, A. Stirling, T. Soós and I. Pápai, Angew. Chem., Int. Ed., 2008, 47, 2435.

24 T. A. Rokob, I. Bakó, A. Stirling, A. Hamza and I. Pápai, J. Am. Chem. Soc., 2013, 135, 4425.

25 F. Bertini, F. Hoffmann, C. Appelt, W. Uhl, A. W. Ehlers, J. C. Slootweg and K. Lammertsma, Organometallics, 2013, 32, 6764.

26 (a) S. J. Geier and D. W. Stephan, J. Am. Chem. Soc., 2009, 131, 3476; (b) S. Schwendemann, R. Fröhlich, G. Kehr and G. Erker, Chem. Sci., 2011, 2, 1842; (c) C. Jiang and D. W. Stephan, Dalton Trans., 2013, 42, 630; (d) T. Voss, T. Mahdi, E. Otten, R. Frohlich, G. Kehr, D. W. Stephan and G. Erker, Organometallics, 2012, 31, 2367; (e) S. J. Geier, P. A. Chase and D. W. Stephan, Chem. Commun., 2010, 46, 4884; $(f)$ S. J. Geier, A. L. Gille, T. M. Gilbert and D. W. Stephan, Inorg. Chem., 2009, 48, 10466; $(g)$ L. Greb, P. Oña-Burgos, B. Schirmer, S. Grimme, D. W. Stephan and J. Paradies, Angew. Chem., Int. Ed., 2012, 51, 10164; (h) E. L. Kolychev, T. Bannenberg, M. Freytag, C. G. Daniliuc, P. G. Jones and M. Tamm, Chem. - Eur. J., 2012, 18, 16938; (i) C. Jiang, O. Blacque, T. Fox and H. Berke, Organometallics, 2011, 30, 2117; $(j)$ M. Ullrich, A. J. Lough and D. W. Stephan, Organometallics, 2010, 29, 3647; ( $k$ ) M. A. Dureen, C. C. Brown and D. W. Stephan, Organometallics, 2010, 29, 6594.

27 SHELXTL, SHELX-2013, Bruker AXS, Madison WI, http://shelx.uni-ac. gwdg.de/SHELX/index.php.

28 (a) M. Nava and C. A. Reed, Organometallics, 2011, 30, 4798; (b) S. P. Hoffmann, T. Kato, F. S. Tham and C. A. Reed, Chem. Commun., 2006, 767. 